\title{
PEMIKIRAN A. CHAEDAR ALWASILAH TENTANG PENDEKATAN LITERASI (GENRE-BASED APPROACH) DAN PEMBELAJARAN BAHASA ARAB
}

\author{
Fatimah Azzahra Mutmainah \\ fatimahazzahramutmainnah@gmail.com \\ Universitas Islam Negeri (UIN) Sunan Kalijaga Yogyakarta
}

\begin{abstract}
Chaedar Alwasilah is a scholar who often voiced the importance of writing. He proposed two terms as an implication of discourse studies, the literacy literacy approach and the genre-based approach. This is the main point in writing this article, whether these two terms have the same or different implications in language learning. By using descriptive analysis method, the author tries to connect the two terms with Arabic learning. The results show that literacy and genre based approach are different. However, these two terms have the same intentions, such as the emphasis on the importance of writing skills. In relation to Arabic, although the term literacy approach is less well known, this article shows that the concept has also existed in Arabic learning.
\end{abstract}

Keywords: Chaedar Alwasilah, Literacy Approach, Genre-Based Approach.

\section{PENDAHULUAN}

Chaedar Alwasilah merupakan akademisi yang cukup sering menyuarakan pentingnya menulis. Diantara tulisannya juga banyak mengkritik perkembangan budaya menulis atau literasi sekarang yang menurutnya semakin menurun, bahkan di kalangan pegiat bahasa sekalipun. Menurutnya, hal tersebut merupakan ironi, karena, mereka yang mendalami ilmu kebahasaan seharusnya memiliki kemampuan bahasa yang lebih baik dibandingkan dengan pegiat ruang lingkup ilmunya.

Dia juga mengatakan bahwa bila diyakini sebagai alat berpikir, maka studi ilmu bahasa (linguistik dan sastra) seyogianya membekali mahasiswa (apalagi dosennya) kemampuan berpikir kritis (KBK), lebih kritis daripada mahasiswa dan dosen bidang studi lain. Bila bahasa diyakini sebagai alat komunikasi, maka studi ilmu bahasa (linguistik dan sastra) seyogianya membekali mahasiswa (apalagi dosennya) kemampuan berkomunikasi tulis, lebih produktif dan komunikatif daripada mahasiswa dan dosen bidang studi lain. Namun, dalam kenyataannya, kedua hipotesis di atas tidak terbukti. Banyak orang yang kritis dan produktif berkarya tulis padahal mereka tidak berlatar 
belakang linguistik atau sastra. ${ }^{1}$ Artinya, penguasaan pengetahuan kebahasaan, baik pengetahuan deklaratif maupun prosedural, tidak menjamin KBK maupun produktivitas berkarya tulis.

Dalam konteks pendidikan bahasa Arab, salah satu tantangan yang muncul adalah rendahnya minat dan motivasi belajar serta kecenderungan sebagai pelajar atau mahasiswa bahasa Arab untuk "mengambil jalan yang serba instan" tanpa melalui proses ketekunan dan kesungguhan. Hal ini bisa dilihat dari karya-karya dalam bentuk makalah dan skripsi yang menurut Mujib cenderung merosot atau kurang berbobot mutunya. ${ }^{2}$ Hal ini bisa jadi karena kemampuan literasi mahasiswa pendidikan bahasa Arab cukup rendah. Jika mahasiswa tersebut memiliki kemampuan literasi yang selayaknya, mereka akan mampu memproduksi ilmu pengetahuan, seperti apa yang dijelaskan oleh Alwasilah (2012) yaitu'literasi mencakup kemampuan reseptif dan produktif dalam upaya berwacana secara tertulis maupun secara lisan". 3

\footnotetext{
1 A. Chaedar Alwasilah dan Senny Suzanna Alwasilah, Pokoknya Menulis, (Bandung: Kiblat, 2013), Hlm 131

2 Fathul Mujib, Rekonstruksi Pendidikan Bahasa Arab, (Yogyakarta: Pedagogia, 2010),Hlm 87.

${ }^{3}$ A. Chaedar Alwasilah, Pokoknya Rekayasa Literasi, (Bandung: Kiblat, 2012), Hlm 167
}

Dari penjelasan diatas, kita bisa melihat pentingnya pengembangan pembelajaran bahasa yang memberikan perhatian khusus pada produktivitas karya tulis siswa. Pendekatan literasi menurut Alwasilah bertujuan agar siswa mampu menghasilkan wacana. Para sarjana telah membahas mengenai pendekatan pembelajaran bahasa Arab. Disini penulis akan menyebut beberapa yang telah ditulis dalam konteks Indonesia. Muhammad Natsir menguji bagaimana pendekatan analisis morfologi dalam pembelajaran bahasa Arab. ${ }^{4}$ Selain pendekatan analisis morfologi, Relit Nur Edi $^{5}$ Ahmad Muradi $^{6}$ memusatkan perhatian pada pendekatan komunikatif. Mereka berpendapat bahwa bahwa belajar bahasa pada hakikatnya merupakan belajar komunikasi. Inilah yang menjadi dasar asumsi dalam pendekatan ini, termasuk bagi pembelajaran bahasa Arab. Sementara itu, Mohammad Toha menguji bagaimana pembelajaran bahasa Arab dengan pendekatan berbasis sekolah. ${ }^{7}$ Jika

\footnotetext{
${ }^{4}$ Muhammad Natsir, "Pendekatan Analisis Morfologi dalam Pembelajaran Bahasa Arab", Jurnal Albayan, Vol. 9, No. 1, 2017

${ }^{5}$ Relit Nur Edi, "Pendekatan Komunikatif (Al Madkhol Al-ittisholi) dalam Pembelajaran Bahasa Arab", Jurnal Albayan, Vol.4, No.2 2012.

${ }^{6}$ Ahmad Muradi, "Pendekatan Komunikatif dalam Pembelajaran Bahasa Arab, Jurnal Arabiyat", Vol. 1, No. 1, 2014

${ }^{7}$ Mohammad Toha, "Pembelajaran bahasa Arab dengan Pendekatan Manajemen Sekolah",
} 
sebelumnya para sarjana memusatkan perhatiannya pada pendekatan tertentu, maka Subur meneliti pendekatan dan strategi dalam pembelajaran bahasa Arab secara umum. Penelitian-penelitian tersebut menunjukkan kesamaan dengan penelitian ini, yaitu pembahasan mengenai pendekatan pembelajaran bahasa Arab. Namun, berbeda dengan sebelumnya, penelitian ini berfokus pandangan seorang tokoh pendidikan bahasa dalam melihat suatu pendekatan, yaitu pendekatan literasi atau pendekatan berbasis genre.

\section{LANDASAN TEORI}

\section{Pengertian pendekatan}

Menurut Kamus Besar Bahasa Indonesia (KBBI), pendekatan adalah proses, cara, perbuatan mendekati. ${ }^{8}$ Berikut penulis akan paparkan pandangan para sarjana pendidikan bahasa tentang pendekatan. Pendekatan umumnya merupakan sikap atau pandangan tentang sesuatu, yang biasanya berupa asumsi atau seperangkat asumsi yang saling berkaitan. Iskandarwassid dan Sunendar mengatakan bahwa di dalam pengajaran atau pembelajaran bahasa, pendekatan merupakan pandangan, filsafat, atau

Okara: Jurnal Bahasa dan Sastra, Vol. 6, No. 1, 2012.

${ }^{8}$ Ebta setiawan, KBBI offline versi 1.1, 2010 kepercayaan tentang hakikat pembelajaran atau pengajaran bahasa yang diyakini dan tidak perlu dibuktikan lagi kebenarannya. ${ }^{9}$

Adapun menurut Azhar Arsyad, approach atau المدخل dalam bahasa Arab adalah "seperangkat asumsi mengenai hakekat belajar mengajar bahasa. Sifatnya aksiomatik (filosofis)". ${ }^{1}$ Bagi Prof. Anthony, pendekatan merupakan satu aksioma, sesuatu yang baku dan tidak dapat lagi dibantah kebenarannya. Dia mengatakan: "I view an approach-any approach- as a set of correlative assumptions dealing with te nature of language and the nature of language teaching and learning." Pendekatan merupakan seperangkat asumsi berkenaan dengan hakikat bahasa dan hakikat belajar-mengajar bahasa. Menurut Syamsuddin Asyrofi, pendekatan bersifat aksiomatis-filosofis, yakni berorientasi pada pendirian, filsafat dan keyakinan yang tidak perlu lagi dibuktikan kebenarannya. ${ }^{1}$

Pendekatan merujuk pada pandangan tentang terjadinya suatu proses

9 Iskandarwassid dan Dadang Sunendar, Strategi Pembelajaran Bahasa, (Bandung: Remaja Rosydakarya, 2013), Hlm 41

1 Azhar Arsyad, Bahasa Ardb dan Metode Pengajarannya, (Yogyakarta: Pustaka Pelajar, 2004), Hlm 19

Syamsuddin Asyrofi, ${ }^{1}$ Metodologi Pembelajaran Bahasa Arab, (Yogyakarta: Idea Press, 2010), Hlm 76. 
yang masih sangat umum. Wa muna menyebut bahwa dengan kata lain, approach merupakan suatu keyakinan atau pandangan filosofis tentang fitrah bahasa, maka pada hakikatnya approach merupakan praduga (asumsi) yang secara teoritis dianggap kebenaran"umum yang tidak perlu dibuktikan lagi meskipun kemungkinan timbul pembicaraan dalam hal meninjau efektivitas dari suatu metode yang lahir sesuai approach". ${ }^{1}$ Dari berbagai pendapat para sarjana diatas, dapat penulis simpulkan bahwa pendekatan merupakan seperangkat asumsi yang bersifat aksiomatis-filosofis yang kebenarannya tidak diragukan lagi. Pendekatan merupakan dasar yang melahirkan metode-metode dalam pembelajaran bahasa.

\section{Pendekatan berbasis genre}

Di dalam pembelajaran bahasa terdapat banyak macam pendekatan yang lahir dalam merespon perkembangan zaman dan teori sebelumnya. Alwasilah misalnya dalam bukunya yang berjudul "pokoknya rekayasa literasi" menyebut beberapa pendekatan dalam pembelajaran bahasa, seperti pendekatan struktural, pendekatan audiolingual atau dengarucap, pendekatan kognitif dan

\footnotetext{
${ }^{1} \mathrm{Wa}$ Muna, Metodologi ${ }^{2}$ Pembelajaran Bahasa Arab, (Yogyakarta: Teras, 2011), Hlm 13
}

transformatif, pendekatan komunikatif dan pendekatan literasi atau pendekatan genre-based. Pendekatan berbasis genre ini merupakan pendekatan yang cukup akrab dalam pembelajaran bahasa Indonesia. Ketika menjelang Ujian Nasional (UN), guru mata pelajaran bahasa Indonesia biasa mengajarkan pendekatan berbasis genre. Para siswa dilatih untuk menganalisa akan jenis (genre) tulisån tertentu. Oleh karenanya, para siswa di Indonesia umumnya tidak asing dengan pendekatan ini. Namun, bagaimanakah dengan bahasa asing, khususnya bahasa Arab? Apakah terdapat istilah pendekatan berbasis genre atau pendekatan literasi dalam proses pembelajarannya di Indonesia? Penulis akan membahasnya di akhir pembahasan tulisan ini.

Menurut Atmazaki, teori genre dalam pembelajaran bahasa dikembangkan berdasarkan pemerolehan bahasa anak dalam model fungsional sistematis yang menunjukkan bagaimana anak-anak belajar bahasa dan cara mereka mengembangkan teks. Dalam kehidupan sehari-hari, orang dewasa cenderung memberi model genre tertentu dalam wacana mereka dengan anak-anak. Berdasarkan model tersebut, guru perlu menemukan model dan strategi yang siswa telah akrab ketika mereka 
mempelajari bahasa. Atmazaki mengatakan tahap belajar bahasa dengan pendekatan genre ini hendaknya, setidaknya mencakup tiga tahap, yaitu pemodelan, konstruksi bersama, dan konstruksi mandiri. Pertama-tama guru menampilkan model teks yang akan dibuat yang kemudian dianalisa bersama siswa. Dalam menghadapi Ujian Nasional diatas misalnya, siswa diberi teks tertentu dari contoh soal. Setelah siswa mulai memahami karakteristik/skematik teks tersebut, guru dan peserta didik bersamasama membuat teks yang dipelajari itu. Setelah mendiskusikan teks yang dibuat bersama tadi, siswa diminta membuat teks secara mandiri. Hal ini bermanfaat agar peserta didik lebih memahami jenis suatu teks yang membedakannya dengan teks yang lain. Dengan demikian, pembelajaran bahasa menjadi kreatif dan produktif. $^{1} \quad$ Pendapat senada $^{3}$ juga disampaikan oleh Syamsi. Dia memandang pendekatan proses genre ini memungkinkan peserta didil untuk mempelajari bagaimana hubungan antara tujuan dan bentuk genre tulisan tertentu seperti yang mereka susun dalam proses

1 Atmazaki, "Implementasi Kårikulum 2013 Mata Pelajaran Bahasa Indonesia”, Dalam Proceeding of the International Seminar on Language and Arts, FBS Universitas Negeri Padang, 2013. yang berulang mulai dari pramenulis, penulisan draf, revisi, dan penyuntingan. ${ }^{1}$

Hammond dkk, sebagaimana dikutip dari Natsir, mengatakan bahwa pendekatan berbasis genre ialah cara menggabungkan pemahaman genre bersama antara genre unsur bahasa, kontek dengan genre mengajar di kelas. Natsir juga mengatakan bahwa pendekatan berbasis Genre sering juga disebut dengan " English for Academic Purposes" atau "English for Specific Purposes approach". ${ }^{1}$ Jika pendekatan berbasis genre diartikan sebagai pembelajaran bahasa untuk tujuan khusus, maka dalam pembelajaran bahasa Arab juga telah ada yang mengusung ide ini. Pada tingkat pendidikan tinggi (universitas), jurusan pendidikan bahasa Arab Universitas Islam Negeri Sunan Kalijaga Yogyakarta telah mengembangkan bahasa Arab untuk tujuan tertentu. Mirip dengan pembelajaran bahasa Inggris, nama mata kuliah tersebut yaitu العربية للغرض الخاص.

1 Kastam Syamsi, Model Peran̂gkat Pembelajaran Menulis Berdasarkan Proses Genre bagi Siswa SMP, Litera, Vol. 11, No. 2, Oktober 2012, Hlm 290.

1 M. Natsir "Pendekatan Terpådu Meningkatkan Kemampuan Menulis dalam Bahasa Inggris Mahasiswa Teknik Mesin Politeknik Negeri Lhokseumawe". http://jurnal.pnl.ac.id/wpcontent/plugins/Flutter/fil es flutter/ 1395032169PolinesNasir-jadi.pdf. Diakses pada 26 Desember 2017 
Ini berarti dalam pembelajaran bahasa Arab di Indonesia juga pada hakikatnya telah mengembangkan pendekatan berbasis genre.

Sebagaimana telah disampaikan sebelumnya, pendekatan merupakan seperangkat asumsi yang bersifat filosofis. Penulis akan menyebutkan beberapa asumsi dalam pendekatan berbasis genre. Mukminatien menyebut bahwa Tim Kementrian Pendidikan Nasional Indonesia telah membagi beberapa konsep penting/asumsi dalam genre based approach. Asumsi tersebut diantaranya:

(1) Pembelajaran bahasa adalah aktivitas sosial. Pemahaman suatu bahasa bisa diperoleh ketika peserta didik bersosialisasi dengan orang lain. Asumsi ini merupakan hasil dari kegiatan kolaborasi antara guru dan peserta didik ataupun antara peserta didik satu dan yang lain. Ini berarti dalam pendekatan berbasis genre bukan hanya sekadar belajar bahasa namun juga menganggap aktivitas sosial merupakan aspek yang tidak kalah pentingnya. (2) Peserta didik belajar bahasa. Melalui banyak kegiatan berinteraksi dengan orang lain, peserta didik pun memahami bagaimana menggunakan suatu bahasa secara lisan ataupun tulis. Peserta didik kemudian mengembangkan pengetahuan yang telah mereka dapatkan, seperti bagaimana menggunakan aturan bahasa, memilih kosakata, dan menggunakan cara yang efektif untuk mengungkapkan apa yang ingin mereka sampaikan. (3) Peserta didik belajar melalui bahasa. Dalam hal ini, menurut Mukminatien, peserta didik berusaha menggunakan suatu bahasa dengan baik supaya mereka dapat memperoleh suatu pengetahuan. (4) Peserta didik di bidang bahasa belajar tentang bahasa. Maksud dari belajar tentang bahasa yaitu membangun pengetahuan tentang bagaimana sistem suatu bahasa.

Selain asumsi-asumsi diatas, asumsi (konsep) lain tentang pendekatan berbasis genre yaitu: (5) Pembelajaran bisa menjadi efektif bila guru menjelaskan secara eksplisit mengenai apa yang diharapkan dari peserta didik. Dalam pendekatan genre based approach, peserta didik dibekali pengetahuan yang jelas tentang bagaimana menggunakan bahasa dalam konteks tertentu (genre). Pendekatan ini menekankan pada pentingnya pengetahuan tentang genre dan interaksi peserta didik dengan orang yang memiliki pengetahuan yang lebih misalnya guru ataupun peserta didik lainnya. Dan yang terakhir adalah (6) 
proses pembelajaran bahasa ialah rangkaian langkah-langkah pengembangan kerangka pengetahuan (scaffold) yang memaparkan berbagai macam aspek bahasa. Menurut Vigotsky, sebagaimana dikutip dari Mukminatien yang merupakan pengusul konsep pendekatan berbasis genre, setiap peserta didik memiliki dua level performa, yaitu independent performance dan potential performance. Independent performance yakni kemampuan peserta didik untuk melakukan sesuatu berdasarkan pengetahuan yang sudah mereka miliki. Sedangkan potential performance mengacu pada kemampuan peserta didik melakukan sesuatu setelah mereka berinteraksi sosial atau bekerjasama dengan orang yang memiliki kemampuan lebih. Zona antara independent performance dan potential performance disebut zone proximal development (ZPD), yakni peserta didik berlatih melalui interaksi dengan orang yang memiliki pengetahuan lebih. Vigotsky, sebagaimana dikutip dari Mukminatien menyimpulkan bahwa jika guru memberikan materi atau kegiatan dimana peserta didik sudah mampu melakukannya, peserta didik tidak akan belajar. Sebaliknya, jika guru mendorong peserta didik berinteraksi dalam ZPD mereka untuk memperoleh pengetahuan menuju potential performance, maka perkembangan dalam proses pembelajaran pun dapat dicapai. Brunner sebagaimana disebutkan dalam Mukminatien mengatkan bahwa peran guru dalam interaksi peserta didik dicerminkan dalam istilah scaffolding. Scaffolding merupakan langkah-langkah yang dilakukan dengan mengurangi kadar kebebasan peserta didik dalam melakukan suatu tugas. Hal itu dilakukan agar mereka dapat fokus pada kemampuan yang mereka rasa sulit dalam proses pembelajarannya. $^{1}$

Selain konsep atau asumsi diatas, penulis akan membahas tahapan pembelajaran berbasis genre based approach: (1) building the context. Dalam tahap ini, peserta didik diperkenalkan dengan konteks sosial model jenis teks yang dipelajari. Selain itu, peserta didik mengeksplor fitur dari konteks umum ketika jenis teks tersebut digunakan (dengan realia, gambar, atau media audiovisual) dan tujuan sosial dari teks tersebut. Peserta didik juga menggali lebih jauh konteks yang dipelajari dengan menelaah gaya teks (register), seperti topik, hubungan antara informan dan resipien, saluran komunikasi (dengan 
telepon atau tatap muka), sesuai dengan tujuan pembelajaran dan kebutuhan peserta didik. (2) Modelling and deconstruction of the text. Pada tahap ini, peserta didik menginvestigasi struktur teks yang digunakan pada model teks. Peserta didik juga diajarkan untuk menginvestigasi fitur bahasa, misalnya pilihan kata dan struktur grammar, yang digunakan pada model teks. (3) Joint construction of the text. Peserta didik berkontribusi dalam pembuatan teks sesuai dengan model teks yang telah dipelajari. Adapun kontribusi guru dalam pembuatan teks secara bertahap dikurangi, agar peserta didik dapat menuju potential performance mereka dalam

membuat teks. (4) Independent construction of the text. Tahap ini mewajibkan peserta didik membuat teks secara mandiri. Performa peserta didik kemudian menjadi dasar penilaian pencapaian peserta didik. (5) Linking related texts. Dalam tahap ini, peserta didik mengingat kembali teks yang sudah mereka pelajari dengan menghubungkan melalui contoh teks lain yang memiliki konteks yang sama atau mirip. ${ }^{1}$ Demikian beberapa konsep mengenai genre based approach dari berbagai

1 Ibid, Hlm 1.38-1.39. sumber. Berikut penulis akan paparkan bagaimana pandangan Alwasilah dalam pendekatan literasi.

\section{METODE PENELITIAN}

Penelitian ini akan membahas tentang bagaimana pemikiran A. Chaedar Alwasilah. Pemikiran tersebut kita bisa temukan di artikel, makalah, jurnal ilmiah maupun buku. Oleh karena itu, jenis penelitian ini adalah studi pustaka dengan menggunakan metode deskriptif analitik. Metode ini adalah metode yang digunakan dengan cara menguraikan sekaligus menganalisis. ${ }^{1} \quad$ Selain akan mengurai pemikiran A. Chaedar Alwasilah tentang salah satu pendekatan dalam pembelajaran bahasa (pendekatan literasi), penelitian ini juga akan menganalisis bagaimana pendekatan tersebut dikaitkan dengan pembelajaran bahasa Arab. Alwasilah mengajukan dua istilah yang mengacu pada pendekatan yang menekankan pada pentingnya penguasaan membaca dan menulis, yaitu pendekatan literasi literasi dan pendekatan genre-based. Inilah yang menjadi pijakan utama penulisan artikel ini, apakah mempunyai implikasi yang sama atau

1 Nyoman Kutha Ratna, Metodologi Penelitian: Kajian Ilmu Budaya dan Ilmu Sosial Humaniora pada Umumnya, (Yogyakarta: Pustaka Pelajar, 2010), Hlm 336 
berbeda dalam pembelajaran bahasa. Hal ini dikarenakan penulis mempunyai asumsi bahwa kedua istilah ini mempunyai implikasi yang berbeda. Sebelum membahas hal tersebut, penulis akan membahas apa yang dimaksud dengan pendekatan terlebih dahulu.

\section{HASIL DAN PEMBAHASAN}

\section{Genre based approach adalah}

pendekatan literasi?

Seperti yang disebutkan sebelumnya, Alwsilah menyebut bahwa pendekatan literasi atau pendekatan genre-based merupakan salah satu pendekatan dalam pembelajaran bahasa, sebagai implikasi dari studi wacana. ${ }^{1}$ Dari pertanyaan tersebut, menurut penulis, Alwasilah menyamakan dua istilah, yaitu "pendekatan literasi" dan "pendekatan genre-based". Apakah memang seperti itu? Jika kita ingin menerjemahkan ke dalam bahasa Inggris, maka kedua istilah ini akan menjadi literacy approach untuk pendekatan literasi dan genre based approach untuk pendekatan berbasis genre. Dari sini sebenarnya menunjukkan bahwa kedua istilah tersebut berbeda. Diatas penulis telah jelaskan tentang pendekatan berbasis genre. Adapun Alwasilah telah paprkan dalam bukunya secara rinci mengenai apa itu literasi, dan tidak membahas tentang pendekatan berbasis genre. Hal ini bisa dipahami karena bukunya memang membahas seputar masalah literasi. Namun, mengapa Alwasilah memberikan arti yang sama untuk kedua istilah tersebut?

Menurut penulis, kedua istilah tersebut diartikan sama bukan tanpa alasan. Kedua istilah tersebut menunjukkan perlunya pendekatan pembelajaran bahasa yang menekankan penguasaan keterampilan bahasa, khususnya menulis. Penjelasan mengenai pendekatan genre diatas bermanfaat untuk menampilkan sejauh mana persamaan dan perbedaan yang terdapat diantara kedua istilah tersebut. Dan berikut penulis akan memaparkan beberapa konsep yang Alwasilah ajukan mengenai literasi, yang bersumber dari buku yang berjudul “pokoknya rekayasa literasi”.

Alwasilah menyebut tujuh prinsip pembelajaran bahasa berbasis literasi. Berikut tujuh prinsip tersebut. (1) Literasi merupakan kecakapan hidup (life skills) yang memungkinkan manusia berfungsi maksimal sebagai anggota masyarakat. (2) Literasi meliputi kemampuan reseptif dan produktif dalam upaya berwacana

1 A. Chaedar Alwasilah, Pokoknya 
tertulis maupun secara lisan. (3) Literasi yakni kemampuan memecahkan masalah. (4) Literasi ialah refleksi penguasaan dan apresiasi budaya. (5) Literasi merupakan kegiatan refleksi (diri). (6) Literasi adalah hasil kolaborasi. Dan (7) Literasi adalah kegiatan melakukan interpretasi.

Jika kita kembali ke pembahasan mengenai diatas, maka kita bisa melihat bahwa pendekatan literasi dan pendekatan berbasis genre memiliki persamaan, meskipun juga terdapat perbedaan. Contohnya yaitu pendekatan berbasis genre mempunyai konsep bahwa belajar bahasa merupakan aktivitas sosial. Konsep literasi pun mengusung ide yang senada, dimana memaksimalkan kemampuan manusia sebagai anggota masyarakat. Sebagai implikasinya, dalam pembelajaran bahasa dalam pendekatan berbasis genre menekankan akan pentingnya hasil kolaborasi guru dan peserta didik. Asumsi ini juga sama dengan maksud literasi yang merupakan hasil kolaborasi. Namun, meskipun begitu, jika kita kembali ke pembahasan pendekatan berbasis genre diatas, maka umumnya pembahasannya lebih menekankan pada kemampuan menulis. Sedangkan menurut Alwasilah, dalam pendekatan literasi juga memperhatikan

Rekayasa ..., Hlm 159. kemampuan berbahasa lainnya, termasuk lisan. Dan yang menarik dari prinsip literasi diatas adalah terdapat apresiasi terhadap budaya, yang tidak kita temukan di pembahasan sebelumnya.

\section{Kaitan Pendekatan Literasi Menurut} Alwasilah dengan Pembelajaran

\section{bahasa Arab}

Pembahasan pada bagian ini merupakan respon terhadap konsep Alwasilah tentang literasi di dalam bukunya yang berjudul "Pokoknya Rekayasa Literasi”. Pembahasan berikut merupakan kaitan konsep-konsep tersebut dengan pembelajaran bahasa Arab, baik itu pembuktian bahwa pembelajaran bahasa Arab sebenarnya sudah menggunakan konsep literasi meskipun dengan bentuk yang berbeda maupun berupa saran demi kemajuan pengembangannya. Berdasarkan pembacaan pada buku tersebut, penulis membagi literasi ke dalam dua pengertian, yakni dalam arti luas dan arti sempit.

Literasi dalam arti luas dimaksudkan bahwa literasi itu berkaitan dengan aspek sosial, masyarakat, politik, budaya, dll. Maksudnya yaitu lebih luas dari sekadar dunia pembelajaran bahasa. Alwasilah berpendapat bahwa literasi adalah kemampuan menggunakan simbolsimbol tulis sebagai keterampilan hidup agar semua warga negara demokratis 
dapat berperan maksimal dalam masyarakat madani. Dari definisi tersebut tampak bahwa literasi mempunyai peran dalam kehidupan sosial masyarakat, bukan hanya berkaitan baca-tulis semata. Selain itu, literasi dalam arti luas juga berkaitan dengan hal-hal berikut. Alwasilah mengatakan kunci tercapainya literasi yaitu adanya ketertiban lembagalembaga sosial, standar dunia, warga masyarakat demokratis, keragaman lokal, hubungan global, kewarganegaraan yang efektif dan masyarakat semiotik. Oleh karena itu, literasi bisa tercapai ketika ada partisipasi dari segala segala pihak, bukan hanya akademisi pendidikan bahasa.

Selain itu dia mengemukakan salah satu prinsip literasi yakni literasi merupakan kecakapan hidup (life skills) yang memungkinkan manusia berfungsi maksimal sebagai anggota masyarakat. Penjabaran mengenai prinsip ini cukup baik apabila diterapkan dalam pembelajaran bahasa Arab. Pembelajar bahasa Arab yang diajarkan pendekatan literasi akan menggunakan bahasa yang dipelajarinya dalam kehidupan nyata, seperti membuat $\mathrm{CV}$, surat lamaran kerja, membaca menu, dan membaca jadwal penerbangan dalam bahasa Arab. Hal tersebut bermanfaat bagi pembelajar bahasa Arab agar dapat berpartisipasi

aktif sebagai anggota masyarakat untuk saling membantu dengan yang lainnya.

Adapun dalam arti sempit, literasi berkaitan dengan bahasa maupun pengajarannya. Berikut penulis akan sampaikan beberapa poin pendekatan literasi dalam arti sempit menurut Alwasilah dan relevansinya dengan pembelajaran bahasa Arab. Alwasilah telah merumuskan 10 frase kunci dalam literasi. Salah satunya adalah tingkat kefasihan yang relatif. Dalam pembelajaran bahasa Arab pun sebenarnya terdapat konsep serupa. Contohnya adalah untuk meningkatkan kemampuan bahasa Asing di UIN Sunan Kalijaga, kampus menerapkan kefasihan (literasi) minimal, yaitu nilai 400 bagi IKLA (اختبار كفاءة اللغة العربية) untuk jenjang sarjana . Tes-tes tersebut merupakan syarat yang wajib diikuti oleh seluruh mahasiswa agar bisa munāqosyah (sidang) skripsi. Menurut asumsi penulis, hal ini bertujuan agar para mahasiswanya terbiasa dan akrab dengan bahasa asing dan bahkan bisa menggunakan literasi bahasa asing dengan baik.

Selain tingkat kefasihan relatif, frase kunci literasi lain menurut Alwasilah adalah perkembangan potensi diri dan pengetahuan. Literasi membekali orang kemampuan mengembangkan segala potensi dirinya. Semakin tinggi 
kemampuan literasi (baca-tulis) seseorang, maka ia semakin bisa mengembangkan potensinya dengan baik. Sebagai contoh, jika mahasiswa pendidikan bahasa Arab memiliki literasi yang baik, tentu ia akan mudah berkreasi dalam bahasa arab pula. Oleh karena itu, dia telah berhasil menguasai kompetensi professional, yaitu salah satu kompetensi yang harus dimiliki guru atau calon guru.

Alwasilah membagi 7 dimensi dalam literasi. Selanjutnya, penulis akan mengaitkan beberapa dimensi tersebut dengan pembelajaran bahasa Arab. (1) Dimensi Geografis. Literasi seseorang dapat dikatakan berdimensi lokal, nasional, regional, atau internasional bergantung pada tingkat pendidikan dan jaringan sosial dan vokasionalnya. Misalnya ketika seseorang yang berbahasa ibu non-Arab memilih jurusan bahasa Arab, berarti ia membuka peluang untuk memliki literasi internasional. (2) Dimensi Keterampilan. Literasi seseorang tampak dalam kegiatan membaca, menulis, menghitung, dan berbicara. Setiap sarjana pasti mampu membaca, tapi tidak semua sarjana mampu menulis. Hal ini pun berlaku bagi sarjana bahasa Arab. Bagi mahasiswa bahasa Arab yang pernah mengenyam pendidikan di pesantren tradisiomal misalnya, sebagian besar dari mereka cukup pandai membaca bahasa Arab gundul, tetapi ketika disuruh menulis atau berbicara, maka mereka akan kesulitan untuk melakukan hal tersebut. (3) Dimensi Bahasa. Contoh dimensi ini adalah bagi orang Jawa yang mempelajari bahasa Arab misalnya, maka dia adalah orang yang multilingual dalam bahasa Jawa, Indonesia dan Arab. Artinya, dia multiliterat.

Pada pembahasan sebelumnya telah dijelaskan mengenai prinsip pendekatan literasi menurut Alwasilah. Penulis kemudian akan menjelaskan beberapa prinsip literasi berikut kaitannya dengan pembelajaran bahasa Arab. Dia mengatakan bahwa literasi mencakup kemampuan reseptif dan produktif dalam upaya berwacana baik tertulis maupun secara lisan. Pendidikan bahasa sejak dini membiasakan siswa berekspresi, baik secara lisan maupun secara tulis. Hal ini juga berlaku bagi pendidikan bahasa Arab. Bagi mahasiswa bahasa Arab dikatakan memliki literasi dalam bahasa Arab apabila ia bisa mereproduksi ilmu pengetahuan berupa makalah, karya ilmiah, skripsi, dll baik dalam bahasa ibu terlebih bahasa Arab itu sendiri. Oleh karena itu, para penyelenggara pembelajaran bahasa Arab diharapkan mampu membuat siswanya produktif menghasilkan karya-karya tersebut. 
Selain itu, Literasi merupakan kemampuan memecahkan masalah. Dalam penjelasan mengenai prinsip ini Alwasilah berpendapat bahwa pendidikan bahasa melatih siswa berpikir kritis. Mengajarkan bahasa seyogianya melatih siswa menggunakan bahasa dengan nalar. Sebagai contoh ketika dosen yang mengajarkan menulis (Kitābah) bahasa Arab, ia bisa meminta mahasiswanya untuk menulis hal-hal yang berkaitan dengan isu hangat. Dengan begitu, kemampuan nalar dan kritis mahasiswanya diuji, selain juga melihat kemampuan literasi mereka. Selain itu juga dengan pemikiran yang dimiliki siswa bisa jadi menemukan masalah tersebut.

Selanjutnya, literasi bagi Alwasilah ialah kegiatan refleksi (diri). Refleksi dalam hal ini merupakan konstruk atau pemahaman yang terus berkembang dan semakin canggih (development construct). Semakin seseorang mempelajari bahasa Arab, maka pemikiran-nya akan semakin berkembang dan ia akan melakukan refleksi atas bahasa sendiri maupun bahasa Arab. Lebih lanjut lagi, literasi menurut Alwasilah merupakan hasil kolaborasi. Pendidikan bahasa sejak dini sejatinya melatih siswa menggunakan bahasa melalui kegiatan kolaboratif.
Literasi berbentuk skripsi misalnya, itu bukan hanya hasil penulisnya semata, tetapi juga terdapat kolaborasi pemikiran dengan dosen pembimbingnya. Begitu juga dengan pembelajaran bahasa Arab. Dalam kegiatan menulis (kitabah) guru menganjurkan atau menyarankan sesuatu terhadap tulisan siswa. Dari situ, karya tulisan siswa merupakan hasil kolaborasi ia dengan gurunya.

Dan yang terakhir yang akan dibahas di artikel ini adalah pandangan Alwasilah yang mengatakan literasi merupakan kegiatan melakukan interpretasi. Dalam pembelajaran bahasa Arab, contohnya adalah interpretasi atas kitab-kitab kuning. Hal ini akan bermanfaat bagi lintas disiplin ilmu yang berkaitan dengan agama Islam, seperti Fiqh, kalam, filsafat, dll. Hal ini sesuai dengan pendapat A. Chaedar Alwasilah bahwa "pendidikan bahasa sejak dini seyogianya melatih (maha)siswa melakukan interpretasi (mencari, menebak, dan membangun makna) atas berbagai jenis teks dalam wacana tekstual, visual, dan digital di berbagai ranah kehidupan dan bidang ilmu". ${ }^{2}$

Kucer menyebut ada tiga paradigma dalam pembelajaran literasi, sebagaimana yang dikutip oleh A. 
Chaedar Alwasilah, yaitu decoding, skills, dan whole language. ${ }^{2}$ Disini penulis akan membahas ketiga paradigma tersebut dan dikaitkan dengan pembelajaran bahasa Arab. Paradigma pertama yaitu decoding. Maksud dari paradigma ini yaitu belajar bahasa dimulai dengan menguasai bagianbagian bahasa. Siswa diajari formula bahasa yang berguna untuk diterapkan pada berbagai peristiwa literasi dalam berbagai konteks. Pembelajaran terpisah seperti ini memiliki kesamaan dengan teori bagian-bagian (نظرية الفروع) dalam pembelajaran bahasa Arab. Mahmud Yunus menyatakan bahwa bahasa yang akan diajarkan itu dibagi atas beberapa bagian (cabang-cabang). ${ }^{2} \quad$ Tiap-tiap cabang tersebut mempunyai kitab dan terdapat jam pelajaran khusus, seperti membaca, mahfudzat, bercakap-cakap, nahwu, sharaf, dikte, balaghah, dll. Kaitannya dengan paradigma diatas yaitu misalnya ketika siswa mempelajari ilmu nahwu, maka dia akan mudah membaca (memahami kode bahasa) dalam bahasa Arab.

Paradigma yang kedua yaitu keterampilan, yang menyatakan bahwa penguasaan morfem dan kosakata

\footnotetext{
2 A. Chaedar Alwasilah, Pokoknya Rekayasa ..., Hlm 168

2 Ibid, Hlm 177.
}

merupakan dasar membaca. Alwasilah ${ }^{I}$ kemudian menjelaskan siswa dilatih menguasai reading comprhehension sebagai bagian dari penguasaan kosakata (baru). Fokus pembelajaran pada paradigma ini diletakkan pada penguasaan sistem morfemik bahasa. Melalui proses ini, pembelajar diharapkan mampu berliterasi secara mandiri. Dalam pembelajaran bahasa Arab, siswa diajarkan tentang formulasi bahasa, seperti șarf dan mufradāt dahulu. Ini bertujuan agar siswa/pembelajar bahasa Arab bisa memaknai literasi (suatu teks bacaan misalnya) secara mandiri. Setelah itu, dia menerapkan kemampuan tersebut sebagąi bahan untuk berliterasi dalam persoalan yang lebih kompleks. Pada tahap awal, dia hanya pembelajar pasif, artinya dia menerima ilmu-ilmu tentang literasi; seperti membaca teks untuk memaknai kode. Kemudian dia belajar literasi, misalnya dengan membuat tulisan berbahasa Arab. Setelah melewati tahap itu, siswa tersebut akan belajar melalui literasi yang berhasil ia hasilkan.

$$
\text { Paradigma yang terakhir dalam }
$$
literasi adalah bahasa secara utuh. Berbeda dengan paradigma diatas yang menekankan pada bagian bahasa,

2 Mahmud Yunus, Metodik Rhusus Bahasa Arab (Bahasa Al-Qur'an), (Jakarta: Hidakarya Agung, 1983), Hlm 28 
paradigma yang ketiga ini mengasumsikan bahwa bahasa itu sejatinya sesuatu yang utuh. Alwasilah menyebut bahwa pengajaran bahasa dalam paradigma ini mesti berfokus pada pembelajaran bahasa, yaitu kegiatan mengajarkan makna secara utuh, tidak parsial. Paradigma ini memiliki kesamaan dengan teori kesatuan (نظرية الوحدة) dalam pembelajaran bahasa Arab. Menurut Mahmud Yunus, teori kesatuan adalah bahasa Arab itu diajarkan sebagai salah satu kesatuan yang berhubungan erat, bukan dibagi-bagi atas beberapa bagian (bercabang-cabang) yang bercerai berai. Menurut teori ini diambil satu acara sebagai pusat, lalu dijadikan bacaan, percakapan, nahwu/sharaf dan sebagainya. Dengan demikian tidak ada jam khusus untuk membaca, untuk bercakap-cakap, untuk nahwu/sharaf dan sebagainya. Hanya ada beberapa jam untuk bahasa Arab. ${ }^{2}$

Selain hal diatas, hal lain yang kiranya perlu dibahas yaitu pandangan Alwasilah yang menyatakan bahwa bahasa adalah fenomena sosial. Baginya, pendekatan literasi lebih banyak memandang teks sebagai realisasi tindakan komunikasi. Hal ini menjelaskan kepada kita bahwa belajar bahasa bukan "hanya" ihwal tata bahasa saja, tetapi juga sebagai fenomena sosial. Sebagai contoh, bahasa ' $\bar{A}$ miah (non-resmi) yang beragam pada bahasa Arab adalah suatu fenomena sosial. Bahasa Arab yang dikenal di Indonesia dalam bahasa fushah (resmi) telah mengalami perubahan di negaranegara pemakainya. Mengenai paradigma literasi, Alwasilah memberikan penjelasan sebagai berikut.

"Paradigma adalah cara pandang dan pemaknaan terhadap objek pandang (baca: pengajaran literasi). Perubahan sudut pandang membawa sejumlah konsekuensi sampai ke metode dan teknik pengajaran yang kasat mata dan hasilnya dapat diukur. Misalnya, dengan perubahan orientasi dari hasil ke proses, guru bahasa akan melakukan hal-hal seperti: (1) bagi dia isunya bukan apa atau berapa banyak tulisan yang dihasilkan siswa, melainkan bagaiman tulisan itu diproses dari A sampai dengan $Z$, (2) tidak menentukan target yang sama bagi semua siswa, misalnya seribu kata esai naratif, karena dalam proses menulis

${ }^{2}$ Ibid, Hlm 26-27. 
setiap siswa memiliki hobi dan gaya yang berbeda."

Dalam konteks pembelajaran bahasa Arab, pada mata kuliah kitabah misalnya. Dosen memberikan tugas untuk bernarasi dengan menggunakan bahasa Arab. Dari awal perkuliahan hingga akhir, dosen memantau, menilai dan mengoreksi perkembangan karangan mahasiswanya. Jika mengacu dengan pernyataan Alwasilah diatas, maka penilaian bukan berdasarkan dari tulisan akhir yang bagus, tetapi hasil selama berproses hingga menghasilkan tulisan akhir. Hal ini akan membantu mahasiswa bahasa Arab yang sebelumnya tidak pernah belajar bahasa Arab. Meskipun dalam konteks ini, posisi bahasa Arab dan bahasa Inggris di Indonesia berbeda. Oleh karena itu, siswa-siswa Indonesia mempelajari bahasa Inggris dari tingkat SD hingga SMA. Hal ini berbeda dengan bahasa Arab, dimana tidak semua mahasiswa bahasa Arab sudah mempelajarinya pada jenjang sebelumnya. Sehingga misalnya penilaian mata kuliah kitabah hanya melihat hasil akhirnya, maka mahasiswa yang "baru" mempelajari bahasa Arab akan mendapatkan nilai yang relatif rendah.

\footnotetext{
2 A. Chaedar Alwasilah, Pokoknya Rekayasa ..., Hlm 179.
}

Wacana pembelajaran bahasa selama ini terfokus pada empat keterampilan bahasa, yaitu menyimak, berbicara, membaca, dan menulis. Menurut Alwasilah pembelajaran bahasa asing kurang mengenal istilah pendekatan literasi. Pengenalan terhadap berbagai teks seperti iklan, ramalan cuaca, jadwal keberangkatan kereta api, rambu-rambu lalu-lintas, resep dokter, menu makanan, surat lamaran, editorial koran, puisi, cerita pendek, dan sebagainya merupakan bagian dari pengenalan literasi. Dalam pembelajaran bahasa Arab, contoh-contoh literasi yang disebutkan oleh Alwasilah tersebut juga jarang diajarkan. Padahal, hal tersebut cukup penting dipelajari. Jika contoh-contoh tersebut tidak diajarkan, maka ketika mahasiswa bahasa Arab ingin membuat lamaran kerja dalam bahasa Arab misalnya, dia mungkin akan kesulitan. Hal ini dikarenakan dia belum memiliki pengalaman atau tidak dikenalkan akan hal tersebut.

Menurut A. Chaedar Alwasilah, pengajaran membaca dan menulis harus ditempatkan dalam keempat dimensi yang saling terkait, yaitu pengetahuan kebahasaan (fokus pada teks),pengetahuan kognitif (fokus pada minda), pengetahuan perkembangan (fokus pada pertumbuhan) dan pengetahuan sosiokultural (fokus pada 
kelompok). Pengajaran bahasa yang baik bagi Alwasilah menghasilkan orang literat yang mampu menggunakan keempat dimensi ini secara bersamaan, aktif, dan terintegrasi. Di dalam pembelajaran bahasa Arab, keempat dimensi ini sangat penting dikuasai. Pembelajar yang literat dalam bahasa Arab, dia akan membaca dan menulis dengan memenuhi keempat pengetahuan itu.

\section{SIMPULAN DAN SARAN}

Dari berbagai penjelasan diatas, penulis dapat menyimpulkan bahwa kedua istilah yang diajukan oleh Alwasilah, yaitu pendekatan literasi dan pendekatan genre-based merupakan sesuatu yang berbeda, meski sebenarnya menunjukkan maksud yang sama dalam pembelajaran bahasa. Diatas telah dijelaskan bahwa persamaan tersebut terletak pada perhatian yang khusus terhadap kemampuan membaca dan menulis. Jika penelitian yang dilakukan para sarjana biasanya mengembangkan metodologi pembelajaran bahasa dengan menggunakan penelitian lapangan, maka studi ini terbatas pada studi pustaka. Keadaan ini menuntut adanya penelitian lanjutan lagi tentang literasi maupun pendekatan berbasis genre menggunakan studi lapangan. Selain itu, pembahasan mengenai pendekatan berbasis genre dan literasi dalam artikel ini terbatas pada ide Alwasilah dan beberapa sarjana lainnya. Oleh karena itu, artikel ini terbuka akan teori lain yang memperkuat atau bahkan membantah penjelasan yang telah dibahas disini.

\section{DAFTAR PUSTAKA}

Alwasilah, Chaedar dan Senny Suzanna Alwasilah. Pokoknya Menulis. Bandung: Kiblat. 2013.

Alwasilah, Chaedar. Pokoknya Rekayasa Literasi. Bandung: Kiblat. 2012.

Arsyad, Azhar. Bahasa Arab dan Metode Pengajarannya. Yogyakarta: Pustaka Pelajar. 2004.

Asyrofi, Syamsuddin. Metodologi Pembelajaran Bahasa Arab. Yogyakarta: Idea Press. 2010.

Atmazaki. "Implementasi Kurikulum 2013 Mata Pelajaran Bahasa Indonesia". Dalam Proceeding of the International Seminar on Language and Arts. FBS Universitas Negeri Padang, 2013.

Iskandarwassid dan Dadang Sunendar. Strategi Pembelajaran Bahasa. Bandung: Remaja Rosydakarya. 2013.

Kutha Ratna, Nyoman, Metodologi Penelitian: Kajian Ilmu Budaya dan Ilmu Sosial Humaniora pada Umumnya, Yogyakarta: Pustaka Pelajar. 2010.

M. Natsir "Pendekatan Terpadu Meningkatkan Kemampuan Menulis dalam Bahasa Inggris Mahasiswa 
Teknik Mesin Politeknik Negeri Lhokseumawe".

http://jurnal.pnl.ac.id/wpcontent/plugins/Flutter/files flutter/1 395032169PolinesNasir-jadi.pdf. Diakses pada 26 Desember 2017

Mujib, Fathul. Rekonstruksi Pendidikan Bahasa Arab. Yogyakarta: Pedagogia. 2010.

Mukminatien, Nur, dkk. Language Teaching Method. Tangerang Selatan: Universitas Terbuka. 2016

Muna, Wa. Metodologi Pembelajaran Bahasa Arab. Yogyakarta: Teras. 2011.

Muradi, Ahmad. "Pendekatan Komunikatif dalam Pembelajaran Bahasa Arab, Jurnal Arabiyat". Vol. 1, No. 1, 2014.

Natsir, Muhammad. " Pendekatan Analisis Morfologi dalam Pembelajaran Bahasa Arab". Jurnal Albayan. Vol. 9, No. 1, 2017

Nur Edi, Relit. "Pendekatan Komunikatif (Al Madkhol Al-ittisholi) dalam Pembelajaran Bahasa Arab". Jurnal Albayan. Vol.4, No.2 2012.

Setiawan, Ebta. KBBI offline versi 1.1, 2010

Syamsi, Kastam. "Model Perangkat Pembelajaran Menulis Berdasarkan Proses Genre bagi Siswa SMP”. Litera. Vol. 11. No. 2. Oktober 2012.

Toha, Mohammad. "Pembelajaran bahasa Arab dengan Pendekatan Manajemen Sekolah". Okara: Jurnal Bahasa dan Sastra. Vol. 6, No. 1, 2012.

Yunus, Mahmud. Metodik Khusus Bahasa Arab (Bahasa Al-Qur'an). Jakarta: Hidakarya Agung. 1983. 